DOI: 10.20472/IAC.2017.032.018

MARIAMI JIBUTI

Ivane Javakhishvili Tbilisi State University, Georgia

\title{
KEY ISSUES OF COMPETITIVENESS OF AGRICULTURAL SECTOR (THE CASE OF ZEMO SVANETI REGION)
}

\begin{abstract}
:
Work provides discussion of one of the most significant issues in Georgian economy - agrarian sector development, competitiveness and effectiveness of the state policy. In particular, it analyses characteristics of agrarian sector development in Georgia and Zemo Svaneti Region, factors that affect it, its priorities and trends. On the basis of assessment of the natural resources potential of Zemo Svaneti Region the conclusion is made that in this region the focus can be made on bio production.

Work studies, analyses and applies the methodological approaches for competitiveness assessment offered by different scientists, identifies factors hindering agrarian products' competitiveness and to assess their priority the "impact-urgency" matrix. Based on competitiveness determination methodology and Porter's diamond model we have studied strategic agricultural food sectors and their competitiveness.

Work assesses the impact of the state policies dealing with cooperatives and development of the high-mountain regions on Georgia and especially on development of agrarian sector in Zemo Svaneti Region. It analyses formation of service cooperatives and the ways of improvement of Georgian Law on Development of High-Mountain Regions.

Based on the performed studies, the recommendations were formulated for agrarian sector development and state policies improvement at both, national and regional levels.
\end{abstract}

\section{Keywords:}

mountainous region, agriculture, competitiveness, policy.

JEL Classification: Q18 


\section{Introduction}

Development of the agrarian and food sector is a priority for Georgia and for any country. The Georgians were at the beginning of the Agricultural Civilization, and arable farming for them was not just a form of economy, but something that shaped their way of life and mentality [Tvalchrelidze A. Silagadze A. Keshelashvili G. Gegia D. (2011)]. Climate and natural conditions of Georgia provide good possibility for producing ecologically friendly agricultural products. There is an increasing demand for such products on world market [Kharaishvili E. (2015)].

Though, according to data of $1^{\text {st }}$ January 2017, rural population is almost half (42.75\%) of general population in Georgia and most of them are self-employed in farming, for last 8 years share of agriculture in GDP is persistently low (as of $2015,9.2 \%$ only) ${ }^{1}$. The data clearly show that currently, the largest employment opportunity in the country is low-income agriculture. For the most agricultural products the rate of self-sufficiency is low and the deficit is filled with the imported goods. This problem is significant in all regions of the country. Within the scopes of the research targeted region was Zemo Svaneti. This was conditioned by number of significant factors. Goods produced in this region are rare at the markets of capital city and other region centers. Household farms mostly produce for their own consumption. Agrarian production in the region is not provided in a form of business while the region's natural climatic conditions allow local products to take the distinguished niche at the market.

In the process of research the methods of analysis, synthesis and comparison, as well as agrarian sector competitiveness assessment models (Porter's competitiveness diamond model) were used. Work provides assessment of the factors preventing use of competitive advantages using Impact-Urgency priority matrix. In the research process the secondary information was collected and analyzed. Primary information collection was provided using qualitative research methods, focus group meetings and in-depth interviews.

\section{Agrarian Sector Development Trends}

In Georgia, the active population (labor force) includes 2.021.504 people. Employment rate is $88 \%$ where more than half are self-employed in agriculture. Agriculture production is concentrated among small-scale farming households. Around 86.5 percent of total agriculture land has been farmed by 571,900 family holdings. Majority of holdings have small plots; about 77 percent of family holdings have owned at most 1 ha area of land, and average plot size per family holding has been 1.2 ha.

According to the data of 2016, in Georgia, average monthly income of the population, calculated per household, is approximately GEL 962 of which, only GEL 75, i.e. $7.8 \%$ is share of income from selling agricultural production in the total income of household. Like

${ }_{1}^{1}$ National Statistics Office of Georgia, www.geostat.ge 
all other regions of the country, most population of Zemo Svaneti is self-employed. As of 2015 , share of employed in agriculture comprises $63 \%$ of total employment. Cash and noncash incomes from self-employment are quite low and characterized with only slight growth rate from year to year. This figure per capita was only GEL 56.8 in 2015 and GEL 44.1 in 2007. Thus, growth, in nine-year period was only GEL 12.7 (28.8\%). In incomes from selfemployment in agriculture non-cash income is $74 \%$ in average. The population produce agricultural goods for their own consumption.

In Zemo Svaneti Region monthly per capita costs of the population amount to GEL 216.22. In the costs structure, monthly cash costs of agricultural production equal, at least to $3 \%$ (GEL 6.81). This demonstrates that the population's readiness to invest in agriculture is quite low. With respect of the issues of the yield quantities and quality they mostly rely on the nature, climate and other external factors.

In Georgia, share of non-cash costs in all consumer costs for the food varies with regions but this figure is greater than $20 \%$ in all regions. For Samegrelo-Zemo Svaneti Region this figure is $42.5 \%$.

\section{Diagram \#1. Share of non-cash costs of all consumer costs for food by regions}

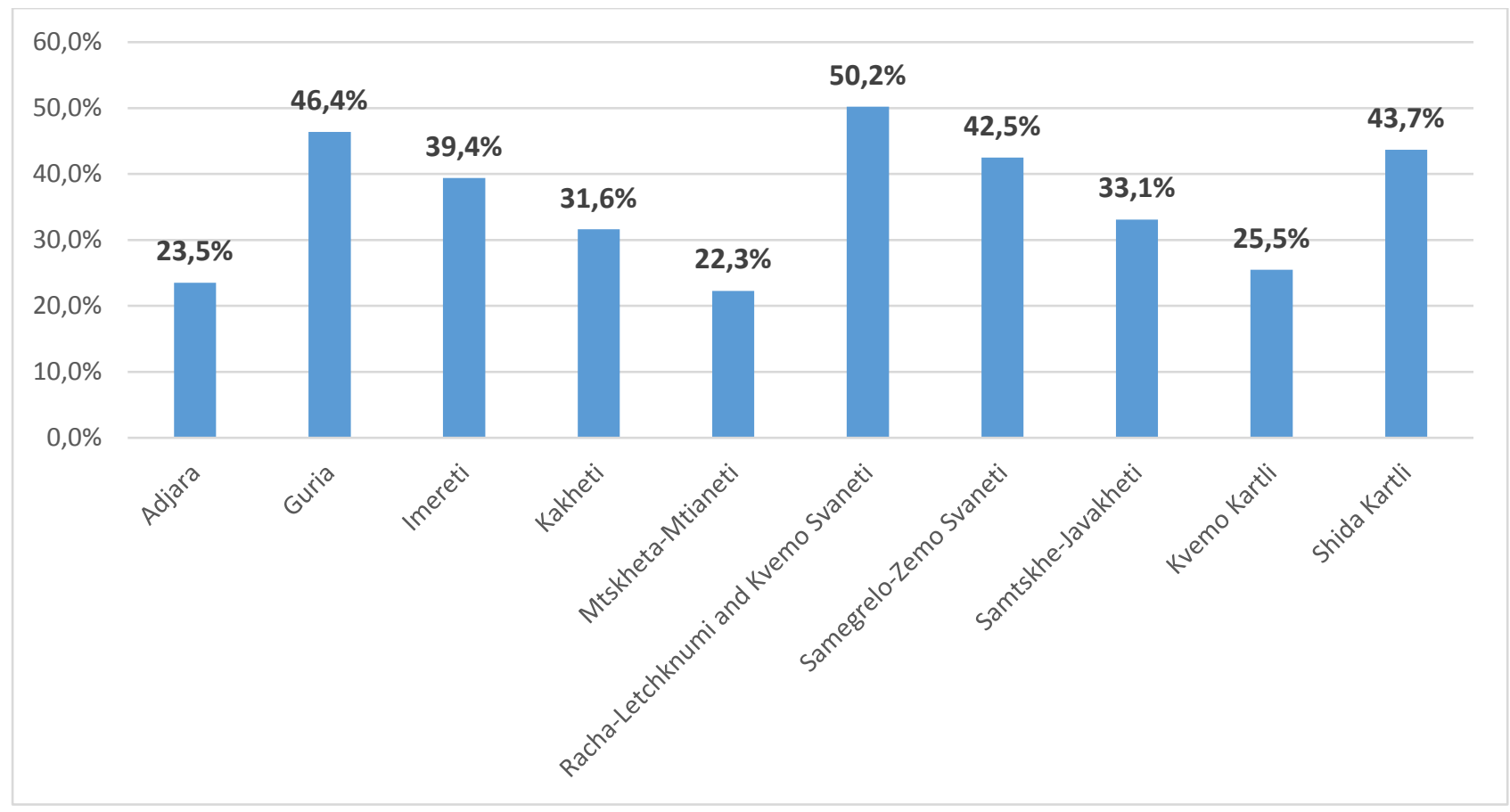

In Zemo Svaneti Region the share of non-cash consumption is $43 \%$ showing that the population meets almost half of its demand by their own production. 
Diagram \#2.Costs distribution of Zemo Svaneti population (\%)

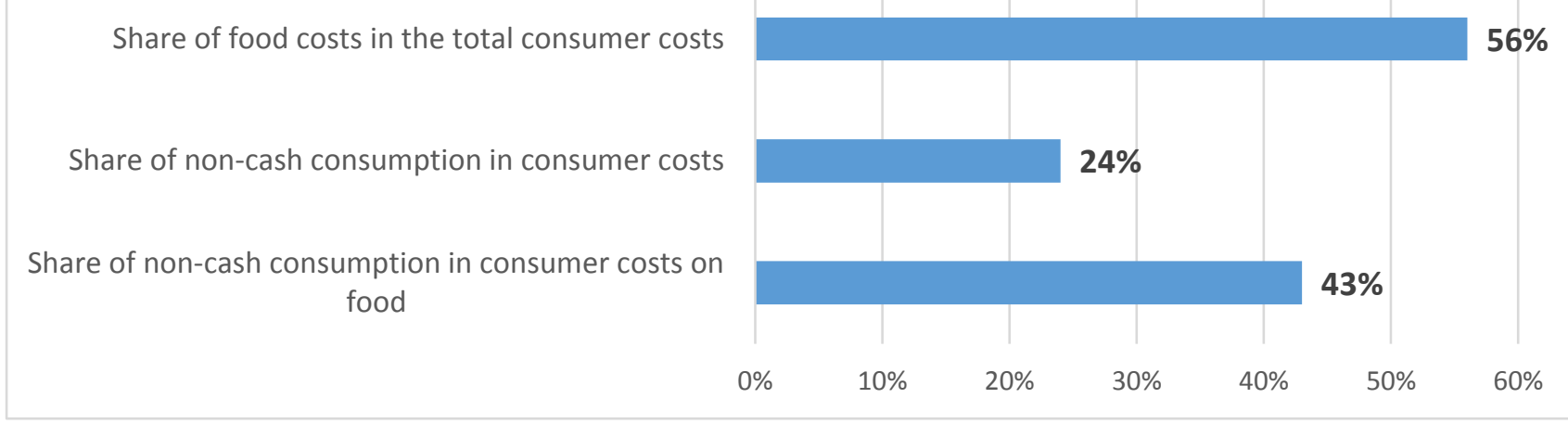

Share of total costs for food comprises $56 \%$ in total consumer costs means that more than half of the population's costs is for the food. In Zemo Svaneti Region, like all other regions of Georgia, the main sphere of activities of the most local population is agriculture. Nevertheless, the share of incomes from sale of agricultural products is insignificant in their total incomes. Population produces agricultural goods basically for own consumption and as a result, costs minimization and economy of scale is impossible.

\section{Factors Hindering Competitiveness of the Agrarian Sector}

Extremely low pace of agrarian sector development in Zemo Svaneti Region is caused by the set of complex factors. They reduce competitiveness of the sector as a whole, as well as that of individual agrarian products.

Diagram \#3. "Impact-Urgency" priority matrix

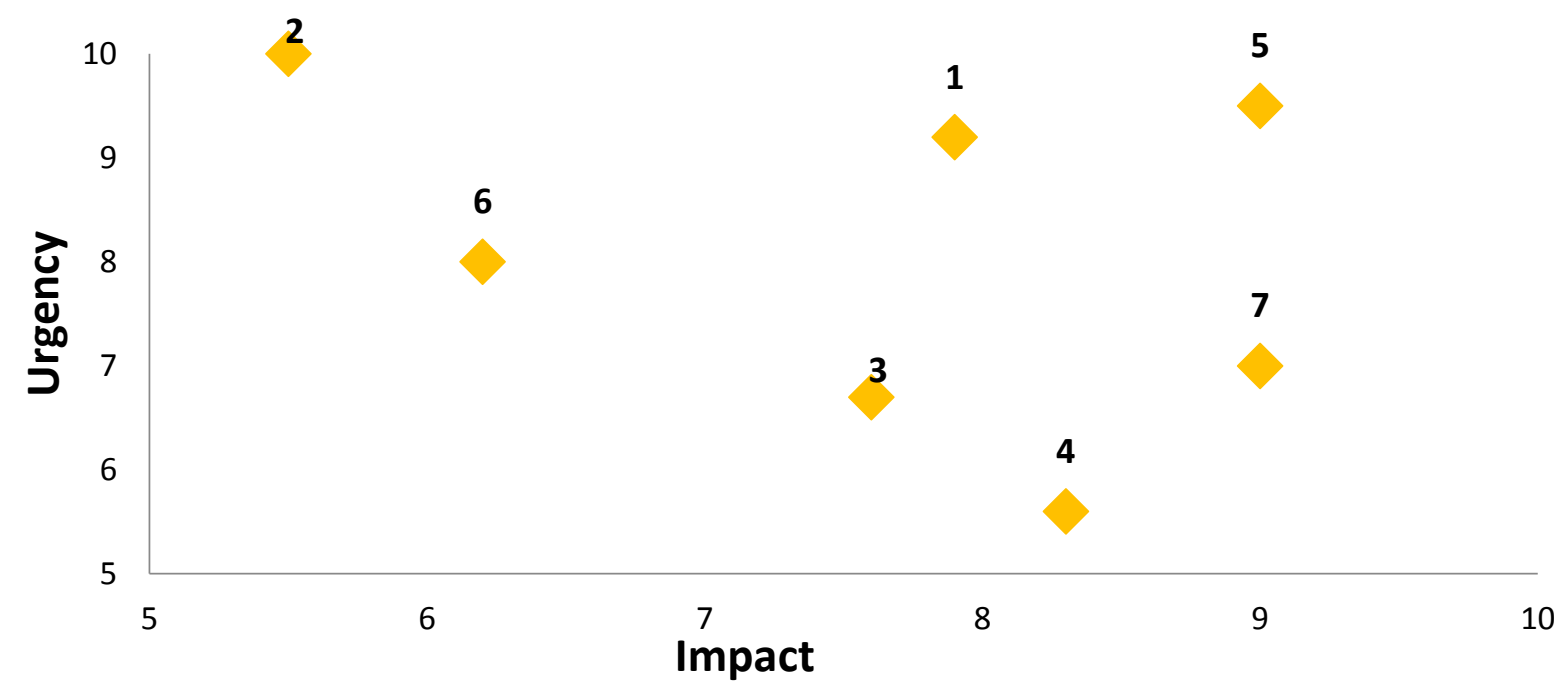


The above diagram provides distribution of the following factors affecting competitiveness of the agricultural products in Zemo Svaneti:

1. Low availability of the machinery - in the region, 84 units of machinery are registered in private ownership, of which only 60 units are in working condition. Most of them are obsolete and amortized.

2. Small holdings and land fragmentation - Zemo Svaneti Region has quite scarce land resources. Total area of agricultural lands is 94.252 ha, of which $96 \%$ are pastures. In the Region, average holding per farmer is 0.47 ha and even this small area is usually in a form of m3-4 different parcels.

3. Low quality of the fertilizers and pesticides - population in the Region rarely use the pesticides. They normally use the natural fertilizers but even where they have such need, the pesticides quality is unsatisfactory. No quality control of the imported fertilizers and pesticides is provided in the country and the farmers have no adequate knowledge for selection of the fertilizers/pesticides, as well as the opportunity to receive qualified consultations.

4. Poor condition of the melioration system - irrigation and drainage channels are inoperable. $80 \%$ of the hay fields are not irrigated at all. While they require irrigation three-four times, mostly are not irrigated at all.

5. Lack of awareness in modern technologies - the population produces agricultural goods relying on the traditional knowledge only. They have no information about modern production technologies allowing improvement of productivity and quality of products. One could say that the absolute majority has no any knowledge in agricultural business management, panning of their household economies, profitability assessment, financial calculations and other business-related issues.

6. Remoteness from the markets - the Region is quite remote from the potential markets. Distance from the regional center to the capital city (Tbilisi) is $477 \mathrm{~km}$ and to the nearest regional center (Zugdidi) - $138 \mathrm{~km}$.

7. Low availability of the services of qualified veterinaries and agronomists - lack of the qualified consultants is a problem in the region. Farmers mostly perform their activities according to the advices of one another.

Among the above factors, the lack of land and remoteness of markets cannot be changed and therefore the other hindering factors should be addressed. Their elimination would allow improvement of the region's agriculture competitiveness.

\section{Competitive Sectors of Agriculture}

As a result of assessment of the agricultural products of Zemo Svaneti Region the sectors that should be developed were identified. These sectors are as follows: potatoes growing, dairy production and bee-keeping. 
Assessment of competitiveness of potatoes growing. Within the scopes of our research we have calculated difference between existing demand for the potatoes and production. As a result we found out that in Zemo Svaneti Region annual demand for potatoes is about 573 tons and harvest of potatoes in 2016 (6.947 tons) was 12 times greater. The problem of products sale for the farmers is apparent. Absence of proper warehousing conditions in the region causes significant loss of the product. Therefore the population is forced to sell the potatoes to the middlemen from Zugdidi, at a price lower than its cost price or exchange by barter for the household goods.

Scheme \#1. Porter's diamond model for potato sector, the weaknesses

\begin{tabular}{|c|c|c|c|c|c|}
\hline $\begin{array}{l}\text { Factors } \\
\text { condition }\end{array}$ & $\begin{array}{l}\text { Demand } \\
\text { conditions }\end{array}$ & $\begin{array}{l}\text { Firm strategy, } \\
\text { structure and } \\
\text { competition }\end{array}$ & $\begin{array}{l}\text { Related and } \\
\text { supporting } \\
\text { sectors }\end{array}$ & State factors & $\begin{array}{l}\text { Chance } \\
\text { factors }\end{array}$ \\
\hline $\begin{array}{l}\text { - lack of the land; } \\
\text { - Hardship of the } \\
\text { land working; } \\
\text { - Poor availability } \\
\text { of the agricultural } \\
\text { machinery; } \\
\text { - Poor condition } \\
\text { of local road } \\
\text { infrastructure; } \\
\text { - Low yield. }\end{array}$ & $\begin{array}{l}\text { - Low purchasing } \\
\text { power of local } \\
\text { market. }\end{array}$ & $\begin{array}{l}\text {-Unawareness } \\
\text { in modern } \\
\text { production } \\
\text { technologies; } \\
\text { - Absence of } \\
\text { proper } \\
\text { conditions for } \\
\text { the products' } \\
\text { storage; } \\
\text { - Products } \\
\text { scattered in } \\
\text { household } \\
\text { economies. }\end{array}$ & $\begin{array}{l}\text { - No potatoes for } \\
\text { seeds are } \\
\text { produced in the } \\
\text { Region; } \\
\text { - Poor } \\
\text { availability of the } \\
\text { special } \\
\text { consultations }\end{array}$ & $\begin{array}{l}\text { - Need of laws } \\
\text { improvement; } \\
\text { - Instable } \\
\text { political } \\
\text { environnment } \\
\text {. }\end{array}$ & $\begin{array}{l}\text {-Remoteness } \\
\text { from the } \\
\text { potential } \\
\text { markets. }\end{array}$ \\
\hline
\end{tabular}

This level of low yield does not surprise considering that the household farmers produce them. They usually own small size of land and have neither experience of intensive farming methods, nor financial resources: according to the WB sources, the investments in agricultural farming becomes profitable if the size of an arable land exceeds 20 ha [Tvalchrelidze A. Silagadze A. Keshelashvili G. Gegia D. (2011)]. 


\section{Scheme \#2. Porter's diamond model for potato sector, existing and potential advantages}

\begin{tabular}{|c|c|c|c|c|c|}
\hline $\begin{array}{l}\text { Factors } \\
\text { condition }\end{array}$ & $\begin{array}{l}\text { Demand } \\
\text { conditions }\end{array}$ & $\begin{array}{c}\text { Firm } \\
\text { strategy, } \\
\text { structure } \\
\text { and } \\
\text { competition }\end{array}$ & $\begin{array}{l}\text { Related and } \\
\text { supporting } \\
\text { sectors }\end{array}$ & State factors & $\begin{array}{l}\text { Chance } \\
\text { factors }\end{array}$ \\
\hline $\begin{array}{l}\text { +Farmers' } \\
\text { traditional } \\
\text { involvement in } \\
\text { the sector; } \\
+ \text { +Low risk of } \\
\text { diseases } \\
\text { spreading in the } \\
\text { soil; } \\
+ \text { Trend of } \\
\text { growth of the } \\
\text { tourists number. }\end{array}$ & $\begin{array}{l}\text { +Local production has } \\
\text { not fully gained the } \\
\text { market (self-supply } \\
\text { coefficient }-91 \% \text { ); } \\
\text { +Trend of growth of } \\
\text { demand for bio products; } \\
\text { +Growing demand for } \\
\text { the agricultural products. }\end{array}$ & $\begin{array}{l}\text { + Products' pre- } \\
\text { packaging, } \\
\text { packaging and } \\
\text { branding } \\
\text { strategies; } \\
\text { +Opportunity of } \\
\text { gaining } \\
\text { competitive } \\
\text { advantages } \\
\text { through } \\
\text { cooperatives; } \\
\text { +Opportunity of } \\
\text { introduction of } \\
\text { the modern } \\
\text { production } \\
\text { techniques } \\
\text { (including crop } \\
\text { rotation). }\end{array}$ & $\begin{array}{l}\text { +Tourism; } \\
\text { +Opportunity of } \\
\text { developing of } \\
\text { agri-tourism; } \\
\text { +Development } \\
\text { of the potato } \\
\text { seeds } \\
\text { production. }\end{array}$ & $\begin{array}{l}\text { +Tax exemptions; } \\
\text { +Policies of } \\
\text { support to the } \\
\text { high mountainous } \\
\text { regions; } \\
\text { +Policies of the } \\
\text { cooperatives' } \\
\text { support. }\end{array}$ & $\begin{array}{l}\text { +Natural } \\
\text { climatic } \\
\text { conditions; } \\
\text { +Consumners' } \\
\text { loyalty to the } \\
\text { goods produced } \\
\text { in the region. }\end{array}$ \\
\hline
\end{tabular}

Assessment of the potential of production and branding of Svanuri Sulguni. Within the scopes of this research we assessed also the difference between the production of milk and dairy products and demand for them. The assessment showed that in Zemo Svaneti Region local demand for the milk and dairy products is about 1.553 .801 litres per year and production is about 5 times higher. Though based on the study conducted in this region we can state that about one third of the local market (33\%) falls on the milk and dairy products that are not produced locally. It is necessary to study and analyze the causes of such dramatic difference between the statistical data and actual situation in the region as incorrect statistical information cannot be relied for development of effective policies for sector development in the region.

Most part of the milk in the region is processed to produce Svanuri Sulguni. Recognition of Svanuri Sulguni is quite high, both in the country and among the tourists. One could say that Svanuri Sulguni is formed as a brand without any trademarks and special packaging, just similar to Racha ham, Tushetian guda cheese and others. In case of proper packaging and branding, Svanuri Sulguni has quite good potential for selling in the shops of the capital city and centers of the other regions.

Assessment of competitiveness of the milk and dairy products using four factors of Porter's diamond model identified the following weaknesses: low average productivity of the cattle 
species in the region; absence of milk processing enterprises; low awareness of the population in the requirements of technical regulations; low productivity of the hay fields and pastures; poorly organized grazing; difficulties of transportation, poor condition of the local road infrastructure; low purchasing power at local market; unawareness in modern production technologies; low availability of the veterinary services and poor development of the fodder production. Assessment of competitive environment by two additional factors showed that the weaknesses of the sector include need for improvement of the laws; instable political environment; poor reliability of statistical information and region's remoteness from the potential markets.

Porter's diamond model also identified the existing and potential advantages. Among the advantages identified by four key factors we should note the possibility of species' refreshment; possibility of creating of the processing enterprise corresponding to the technical regulations' requirements; possibility of development of the fodder production sector. In addition, among additional factors, the significant ones include existence of Svanuri Sulguni as an informal brand. Due to this, fewer efforts are needed for the product popularization. The additional advantages of the sector include: tax exemptions; policies of support to the high mountain regions; policies supportive to dairy cooperatives; naturalclimatic conditions and consumers' loyalty to the products made in this region. All these factors are supportive to development of milk and dairy production in the region.

Assessment of bee-keeping sector development potential. In all settlements of the region there are the farmers engaged in bee-keeping. Bee-keeping is a family tradition for the household economies and both, environmental conditions and high demand for the products are conductive to maintaining and development of this sector. Region's geographical location, rich flora and fauna allow production of high quality honey distinguished with health properties and unique composition. Demand for the honey produced in this region is quite high. It should be noted that the price of honey produced in Zemo Svaneti is $57 \%$ higher than average market price. In 2015, average market price per $\mathrm{kg}$ of honey was GEL 15.92. Price per kg of honey exported from Georgia was USD 8.8 while average price of Chinese honey was USD 1.9 per $\mathrm{kg}$ and price of EU produced honey - USD 6.64 per kg. High price can be regarded as one of the factors preventing growth of honey export. Within the scopes of our research, the weaknesses, existing and potential advantages of bee-keeping sector were assessed using Porter's diamond model.

\section{Scheme \#3. Porter's diamond model for bee-keeping sector, the weaknesses}

\begin{tabular}{|c|c|c|c|c|c|}
\hline $\begin{array}{c}\text { Factors } \\
\text { condition }\end{array}$ & $\begin{array}{c}\text { Demand } \\
\text { conditions }\end{array}$ & $\begin{array}{c}\text { Firm } \\
\text { strategy, } \\
\text { structure } \\
\text { and } \\
\text { competitio } \\
\text { n }\end{array}$ & $\begin{array}{c}\text { Related } \\
\text { and } \\
\text { supportin } \\
\text { g sectors }\end{array}$ & $\begin{array}{c}\text { State } \\
\text { factors }\end{array}$ & $\begin{array}{c}\text { Chance } \\
\text { factors }\end{array}$ \\
& & & & \\
& & & & \\
\hline
\end{tabular}




\begin{tabular}{|c|c|c|c|c|c|}
\hline $\begin{array}{l}\text {-Low productivity; } \\
\text {-Low percentage } \\
\text { of young people's } \\
\text { involvement in } \\
\text { the sector; } \\
\text {-Obsolete } \\
\text { production } \\
\text { inventory; } \\
\text { - Poor condition } \\
\text { of local road } \\
\text { infrastructure }\end{array}$ & $\begin{array}{l}\text { - Low purchasing } \\
\text { power of local market. } \\
\text {-Relatively low prices } \\
\text { of honey at the } \\
\text { national and } \\
\text { international markets. }\end{array}$ & $\begin{array}{l}\text { Unawareness } \\
\text { in modern } \\
\text { production } \\
\text { technologies; }\end{array}$ & $\begin{array}{l}\text {-Low } \\
\text { intensity of } \\
\text { seeding of } \\
\text { the } \\
\text { nectareous } \\
\text { plants. }\end{array}$ & $\begin{array}{l}\text { - Need of } \\
\text { laws } \\
\text { improvement } \\
; \\
\text { - Instable } \\
\text { political } \\
\text { environnmen } \\
t\end{array}$ & $\begin{array}{l}\text { Remoteness } \\
\text { from the } \\
\text { potential } \\
\text { markets. }\end{array}$ \\
\hline
\end{tabular}

\section{Scheme \#4. Porter's diamond model for bee-keeping sector, existing and potential advantages}

\begin{tabular}{|c|c|c|c|c|c|}
\hline $\begin{array}{l}\text { Factors } \\
\text { condition }\end{array}$ & $\begin{array}{l}\text { Demand } \\
\text { conditions }\end{array}$ & $\begin{array}{c}\text { Firm } \\
\text { strategy, } \\
\text { structure } \\
\text { and } \\
\text { competition }\end{array}$ & $\begin{array}{l}\text { Related and } \\
\text { supporting } \\
\text { sectors }\end{array}$ & State factors & $\begin{array}{l}\text { Chance } \\
\text { factors }\end{array}$ \\
\hline $\begin{array}{l}\text { +Farmers' } \\
\text { traditional } \\
\text { involvement in } \\
\text { the sector; } \\
\text { + Proper } \\
\text { environment for } \\
\text { production of } \\
\text { the high quality } \\
\text { honey; } \\
+ \text { Cultivation of } \\
\text { the nectareious } \\
\text { crops. }\end{array}$ & $\begin{array}{l}\text { + Growing } \\
\text { demand for the } \\
\text { high quality } \\
\text { honey. }\end{array}$ & $\begin{array}{l}\text { + Products' } \\
\text { pre-packaging, } \\
\text { packaging and } \\
\text { branding } \\
\text { strategies; } \\
\text { +Opportunity of } \\
\text { gaining } \\
\text { competitive } \\
\text { advantages } \\
\text { through } \\
\text { cooperatives; } \\
\text { +Opportunity of } \\
\text { introduction of } \\
\text { the modern } \\
\text { production } \\
\text { techniques }\end{array}$ & $\begin{array}{l}\text { +Tourism } \\
\text { sector growing } \\
\text { trend; } \\
\text { +Opportunity } \\
\text { of developing } \\
\text { of agri- } \\
\text { tourism; } \\
\text { +Support to } \\
\text { improvement if } \\
\text { the yields in } \\
\text { plant growing; } \\
\text { + Positively } \\
\text { impacts the } \\
\text { environment. }\end{array}$ & $\begin{array}{l}\text { +Tax } \\
\text { exemptions; } \\
\text { +Policies of } \\
\text { support to the } \\
\text { high } \\
\text { mountainous } \\
\text { regions; } \\
\text { +Policies } \\
\text { supporting } \\
\text { honey } \\
\text { producing } \\
\text { cooperatives. }\end{array}$ & $\begin{array}{l}\text { +Natural } \\
\text { climatic } \\
\text { conditions; } \\
\text { +Consumners' } \\
\text { loyalty to the } \\
\text { goods } \\
\text { produced in } \\
\text { the region. }\end{array}$ \\
\hline
\end{tabular}

At current stage, the farmers should primarily address the issue of productivity improvement. This requires use of the modern inventory and technologies in the production process. The farmers use the naturally existing nectariferous plants though they pay little attention to growing of such plants. With growth of production, need for product branding, popularization and promotion would emerge. 
Development of business requires the study of the customer demands and orientation which satisfies and meets these demands. Development of science is increasingly focused on small, medium and large enterprises, on the economic and social motives and future trends of the development of the country [Keshelashvili G. Jibuti M. (2015)].

\section{Assessment of Policy Instruments for Development Agrarian Sector Competitiveness and Effectiveness}

Within the scopes of our study we have analyzed two significant issues: support to the cooperatives and the policy for development of high mountain regions.

Policies for support of the cooperatives development. On July 12, 2013, as a result of joint efforts of the Parliament and Government of Georgia, the legislative body enacted the Law of Georgia on Agricultural Cooperatives which builds upon the best European practice. On September, 20, 2013 a Legal Entity of Public Law Agricultural Cooperatives Development Agency (ACDA) was established under the Law which ensures granting, termination and monitoring of status of agricultural cooperatives, as well as implementation of state programmes. Since 2014, there are the institutional bases for cooperatives development in Georgia. As of 31 December 2016, all over Georgia 1.586 agricultural cooperatives were registered and in Zemo Svaneti their number is only 13.

In order to support cooperatives development ACDA implements the following programs: State Program "Supply of Agriculture Equipment to Agricultural Equipment to Agricultural Cooperatives", State Program on Fostering Hazelnut production development through promotion of agricultural cooperatives, State Program to support Beekeeping Agricultural Co-operatives, State Program to support Dairy Production Agricultural Co-operatives, State Program to support Viticulture Agricultural Co-operatives. About $55 \%$ of the registered cooperatives are the beneficiaries of programs implemented by ACDA. Program beneficiaries of Zemo Svaneti were only 7 cooperatives. Of program beneficiary cooperatives $80 \%$ are included into the program of equipping of the cooperatives with the agricultural machinery; involvement in the other programs is low. Low activity of the cooperatives in Zemo Svaneti Region may be conditioned by the lack of awareness among the farmers, their poor ability to prepare the documentation according to the program requirements. The same could be said about the other regions as well.

Generally, agricultural cooperatives can be divided into two key types. Production cooperatives where the cooperative members jointly produce the goods; they jointly own the production factors (lands, buildings and structures, equipment; mechanization etc.) and jointly use them. Service cooperatives are most widespread cooperatives all over the world. In the associations of such type the members do not consolidate the properties and production factors. The cooperative allows its members to procure the production factors at relatively low price (while before, each of them, individually created retail demand, after cooperation they create the wholesale demand); consolidate the products, process them 
and sell jointly; perform joint marketing activities; receive sectoral consultations and etc. Share of the service cooperatives in agricultural transactions of the developed countries is the highest; for example, in the USA their share is $30 \%$, in EU - 50\% and in Japan - almost $85 \%{ }^{2}$.

In Zemo Svaneti Region, as generally in Georgia, support should be provided to development of the service cooperatives. In the region, the farmers engaged in potatoes growing, can form the cooperative to procure the seeds, fertilizers and other production factors at lower price; introduce bio production; for joint marketing, packaging and sale, similarly with milk processing and bee-keeping areas. For the most cooperatives and individual farmers, access to the markets is limited. They have no distribution channels, some of them have no vehicles/equipment required for transportation. Formation of the marketing cooperatives would allow gaining of the new markets, the farmers would further integrate into the value chain, improve the market power, in relation to the other subjects of market.

Together with technical equipment of the cooperatives it is significant to provide sector consultations to the farmers, as well as the information about the standards and technical regulations. The role of the state and need of support is significant in the process of practical introduction of the standards. At this stage, Agricultural Cooperatives Development Agency (ACDA) is mostly oriented towards support of creation of the processing enterprises though, it should be noted that for effective operation of the processing enterprises availability of the raw materials is required. State Program "Supply of Agricultural Equipment to Agricultural Cooperatives" is terminated at this stage while one could not say that the level of cooperatives' equipping with the machinery is satisfactory. It is recommended that the support of updating of the agricultural machinery and creation of the raw materials base was continued as in many cases, the factor hindering participation in programs is lack of the raw materials basis for processing.

The main problem of agriculture in Georgia is in domination of household subsistence and family holding types of farming. In order to improve the situation it is necessary to enlarge farms in size, to create secondary market and European type of agricultural cooperatives, as it is, for example, established in France [Tvalchrelidze A. Silagadze A. Keshelashvili G. Gegia D. (2011)].

Policies of support to the high mountain regions. Significant instrument for implementation of the policies for development of the high mountain regions is the Law of Georgia on the Development of High Mountain Regions published on 16 July 2015.

For the production entities with the status of the enterprise of high mountain settlement the Law provides tax exemptions. For awarding of the status of high mountain settlement enterprise the entity shall perform its activities only in the territory of high mountain

${ }^{2}$ International Co-operative Alliance, https://ica.coop/en. 
settlement as in the other cases there is a problem with dividing of the enterprise costs, especially the administrative ones.

The status of high mountainous settlement enterprise shall not be granted to an enterprise, where the enterprise carries out: activities which require a license or permission; the provision of services; trade in goods, except in the cases where the goods are processed and delivered.

It should be noted that the Law does not clearly specify the case where the same business entity is engaged in both, activities that are subject to tax exemptions and those, not subject to them. The Law should be revised and required amendments made and the entrepreneurs should be informed that to maintain the status of high mountain settlement enterprise, they shall be engaged in the activities subject to the tax exemptions only.

Within the scopes of the research we have assessed effectiveness of the Law for improvement of competitiveness of agricultural sector. We compared the sector exemptions provided by the Tax Code of Georgia and those provided by the Law of Georgia on the Development of High Mountain Regions. For analysis we identified two directions: primary production and processing.

Table \#1.Case 1 - Tax exemptions when the entrepreneur produces the potatoes (primary production)

\begin{tabular}{|c|c|c|}
\hline Tax & Sector exemption & $\begin{array}{c}\text { Exemptions for the } \\
\text { enterprises of high mountain } \\
\text { settlements }\end{array}$ \\
\hline Income tax & $\begin{array}{c}\text { Natural persons are exempted up to GEL } \\
200,000 \text { limit }\end{array}$ & $\begin{array}{c}\text { Natural persons are exempted up } \\
\text { to GEL } 6,000 \text { limit }\end{array}$ \\
\hline Profit tax & $\begin{array}{c}\text { Profits or profit distribution from primary } \\
\text { production is exempted (i joint income is less } \\
\text { than GEL 200,000) }\end{array}$ & Exempted for 10 years \\
\hline $\begin{array}{c}\text { Value added } \\
\text { tax }\end{array}$ & Primary production is exempted & Real property is exempted \\
\hline Property tax & Movable property is exempted & \\
\hline
\end{tabular}

If the farmer is engaged in primary agricultural production, the Law of Georgia on the Development of High Mountain Regions provides additional exemption from the real property tax. In the high mountain regions, including Zemo Svaneti, land working is very hard and expensive. Exemption from the real property tax allows the farmer to reduce the weaknesses of the competitiveness caused by the environmental conditions. In addition, it should be mentioned that the property tax is not a particularly heavy burden for business 
sector. Hence, the established exemption cannot stimulate the farm economies in the region though it would promote the activities of working farmers.

Table \#2.Case 2 - potato chips producing enterprise (processing)

\begin{tabular}{|l|l|l|}
\hline \multicolumn{1}{|c|}{ Tax } & \multicolumn{1}{|c|}{ Chips producing enterprise } & $\begin{array}{c}\text { Exemptions for the } \\
\text { enterprises of high mountain } \\
\text { settlements }\end{array}$ \\
\hline Income tax & Taxation according to general rules & $\begin{array}{l}\text { Natural persons are exempted up } \\
\text { to GEL } 6,000 \text { limit }\end{array}$ \\
\hline Profit tax & $\begin{array}{l}\text { Taxation according to general rules, reinvested } \\
\text { part of the profit is exempted }\end{array}$ & Exempted for 10 years \\
\hline $\begin{array}{l}\text { Value added } \\
\text { tax }\end{array}$ & Taxation according to general rules & Taxation according to general rules \\
\hline Property tax & Taxation according to general rules & Exempted \\
\hline
\end{tabular}

In such cases the enterprise of high mountain settlement enjoys additional exemptions that would stimulate creation of the processing enterprises in the other, equal conditions through the operation and investment issues should be evaluated: whether the raw materials to be processed are available, what are the costs of the raw materials transportation to the enterprise, whether transportation without losses is possible, whether the required number of workers of relevant qualifications is available, what are the costs of products delivery to the market etc. Regarding the raw material basis existing in Zemo Svaneti Region, we should not that the established exemptions can be stimulating for creation of very small enterprises. Regarding the Region's characteristics, support can be provided to the small fruit processing and milk processing enterprises.

\section{Key Conclusions and Recommendations}

Development of small farming can significantly contribute to socio-economic development and improvement of living condition for a large number of population in Georgia [Kharaishvili E. (2016)].

There are good climatic conditions in Zemo Svaneti Region, recreation and touristic resources, number of the tourists grow annually creating increasing demand for the agricultural products. Though, number of factors hinder agriculture development: low availability of the machinery; small size of land parcels and excessive fragmentation; low quality of the fertilizers, pesticides; poor condition of amelioration system; remoteness from the markets. Development of the livestock, as one of the leading sectors is significantly retarded by poor availability of the qualified veterinary services. In general, involvement of the agronomists in the process of planning and performing of the agricultural activities by the farmers is minimal in the region. The farmers perceive the agricultural activities as the process intended for meeting of the family needs rather than business. Hence, the absolute 
majority of the farmers lack knowledge in the spheres of agribusiness management, planning of their own economies, profitability evaluation, financial calculations and other business-related issues. In many cases the financial operations are not recorded and the farmers are not able to evaluate the cost price of their products and, generally, the profitability of their activities.

Competitive sectors identified based on the assessment of the resources available in the region and agriculture development trends are as follows: potatoes production, livestock and bee-keeping. Opportunity of improving competitiveness of these areas in the Region is quite high at this stage at the national level though in the long run, orientation towards products branding and bio production opens the prospects of gaining world marketplace.

Competitive advantages of the mentioned sectors at this stage are mostly conditioned by the natural-climatic conditions and traditional involvement of the farmers. At the same time, we should admit the state policies supporting development of the high mountain regions and the cooperatives at the legislative level. Though, the analysis showed that the tax exemptions provided by Georgian Law on the Development of High Mountainous Regions mostly provides relief of the tax burden of the entrepreneurs rather than stimulation of commencement of the new business. In addition, the research showed that there is the need of improvement of the law. Consequently, at the first stage, it is necessary to determine the rules for performing of the activities subject to tax exemptions and those not subject to them, within one legal form.

To support improvement of competitiveness of the agriculture sector the emphasis should be made on the following issues:

- Updating of the agricultural machinery fleet - one of the hindering factors preventing agriculture development is poor availability of the agricultural machinery and hence high percentage of manual labor. In addition to the obsolete machinery, the problem is their lack. And improvement of agricultural production effectiveness and reduction of the cost prices directly depends on the use of high quality machinery. Currently most part of the machinery is out of operation and amortized thus delaying performing of the works within the agrarian terms, increase the products' cost price, reduces the yields' quality and production outputs. These problems have particular negative impact on potatoes growing. Hence, updating of the machinery fleet is the precondition for development of this sector.

- Providing special training courses and special consultations to the farmers the farmers are unaware of the new technologies in their sectors. In addition, their absolute majority knows nothing about agribusiness management, planning of their economies, profitability assessment, financial calculations and other business related issues. Together with delivery of the special consultations it is necessary to support the farmers' business management skills. Primarily, it is necessary that the farmers approach to their activities as the business and hence, calculate the cost 
prices of their products, elaborate pricing strategies, maintain the financial documents, plan and organize each agrarian process.

- Promotion of formation of the service cooperatives - to improve competitiveness of the sectors more or less developed in the region, it is desirable that the farmers properly appreciated the benefits of cooperative-type associations. They should understand that cooperation does not necessarily mean consolidation of the properties. In many cases existence of such stereotypes prevent formation of the cooperatives. Hence, it is desirable that the emphasis was made on the service cooperatives' promotion. Such associations would allow their members procurement of the production factors at lower prices; consolidate the products, process and jointly sell them; perform joint marketing activities; receive sector-special and other consultations; jointly study the bio production technologies and introduce them; develop joint refrigerating entities etc.

- Conducting of the frequent information campaigns about agriculture support programs - though ACAD, similar to Agricultural Projects Management Agency (APMA) supports the competitive sectors in Zemo Svaneti Region within the scopes of various programs, involvement of the farmers is quite low. It is necessary that the farmers received full information about the state/donors'/international and other organizations' projects. Together with information supply, they should be assisted through consultations dealing with the program requirements and technical issues. For this, involvement of Mestia Municipality Agriculture Information \& Consultation Service should be improved with effective communication with the Ministry of Agriculture.

- Product branding strategy - products of Zemo Svaneti are highly recognized, both, in the region and at the national level. The main advantages of agricultural products include the production location and tradition. Hence, these advantages should be used by strategy of the products' pre-packaging, packaging and branding. Special emphasis should be made on popularization of Svanuri Sulguni as a brand. Products of Zemo Svaneti Region have the potential of taking special niche at the agricultural products' market. Their positioning should not be provided by the Food Safety Service at the less controlled agrarian markets. Marketing cooperatives provide good opportunity for application of the products branding strategies.

- Production and certification of bio potatoes - trend of growing demand for the bio products create a new and sustainable market for the farmers engaged in potato growing. According to the experts' assessment, sale of bio potatoes is possible at a price $40 \%$ higher than average market prices. Certification would add competitive advantages to the product in relation to the segment of average and high income families. Certification is a challenge for local producers though climatic conditions of the Region provide quite good opportunities. At the first stage the producers should get familiarized with the bio production standards, certification process and develop 
the production action plan together with the consultant, with due regards of the agrarian terms.

- Performing of the marketing activities, collaboration between various businesses in the Region - it is desirable that the local farmers had more opportunities of participation in the national and international exhibitions, forums. Arrangement of small agricultural fair in the Region, at Seti Square would attract the tourists and promote popularization of local products and stimulate the sales.

For the purpose of improvement of recognition the information booklets about advantages of the products from Zemo Svaneti and the farmers can be prepared. It is desired that the farmers involved the local bars, restaurants, hotels and tourist agencies into the distribution network for their products.

\section{References}

Agriculture Review 2006-2015, RAPDI, 2017.

Agriculture Outlook 2015-2024, OECD, FAO, 2015.

Annual Report, Agriculture Research Council, 2014.

Bono, P., Support for Farmers' Cooperatives; Country Report Italy, 2012.

Cadilhon J., Galvez E., Shepherd A., Commodity Associations: a tool for supply chain development?, FAO Agricultural Management, Marketing and Financial Occasional Paper \#24, 2009.

Competitiveness Assessment, USAID, 2014.

Competitiveness of Georgian Agriculture: Investment Case Studies, USAID, 2014.

Cooperation for Rural Prosperity in Georgia, ISET, Tbilisi, December, 2014.

Dadiani L., Building Farmer Cooperatives in Georgia: Supporting smallholder farming in the post-socialist context, 2015.

Docherty C., Branding Agricultural Commodities: The development case for adding value through branding, 2012.

Douwe van der Ploeg J., Werry F., Blom Huib Silvis J., The European Agricultural Model: Perspectives, Prospects and Research Needs, Wageningen University and Research Center, 2014.

Facilitate sustainable linkages of agricultural cooperatives with market players and extension, Evoluxer S.L International Consulting, 2017.

Gloersen E., Martin F. Price, Borec A., Dax T., Giordano B.,, Cohesion in Mountainous Regions of the EU, 2016.

Guideline on Priority Matrix, The University of Queensland, 2012.

Honey Value Chain, ENPARD, 2016

Keshelashvili G., (2016). General Strategies of Georgian Winemaking Companies' Management in the Conditions of Integrated Development, 23rd International Academic Conference, 27-30 April, Venice, Italy. 
http://www.iises.net/proceedings/23rd-international-academic-conference-venice/table-of-content

Keshelashvili G. Jibuti M. (2015). The Commercialization of Ideas and Customer's Needs in the Georgian Market, 15th International Academic Conference, 14-17 April, Rome, Italy.

http://www.iises.net/proceedings/international-academic-conference-rome/front-page

Kharaishvili E., (2011). The Problems of Competition and Competitiveness in Agricultural Sector in Georgia, Tbilisi.

Kharaishvili E., (2016) Small Farm Diversification Opportunities in Viticulture-Winemaking Sector of Georgia, ICEBMM 2016: 18th International Conference on Economics, Business and Marketing Management, Paris, France, May 16-17.

Kharaishvili E., (2015) Farm Diversification and the Corresponding Policy for Its Implementation in Georgia, International Journal of Social, Behavior, Educational, Economic, Business and Industrial Engineering.

Looking Ahead in World Food and Agriculture Perspectives to 2050, Food and Agriculture Organization of the United Nations, 2011.

Mountain policies in Europe, Nordic Centre for Spatial Development, January, 2004.

Philip K. Thornton, Livestock production: recent trends, future prospects, 2010.

Stephan von Cramon-Taubadel, Georgia's agricultural exports, German Economic Team Georgia, Berlin/Tbilisi, 2014.

Sustainable Forest Governance in Georgia: Strengthening Local and National Capacity and Developing Structured Dialogue. CENN, Tbilisi, 2012.

The Renewal of Agricultural Market Information Systems in Developing Countries, FAO, 2014.

The Role of Family Farming in the Sustainable Development of Agriculture Sector and Poverty Reduction, ISET, Tbilisi, December, 2014.

Toloraia I., Angelovski D., Assessment of the constraints faced by selected farmer organizations and legal entities owned by small scale farmers in Georgia to achieve their potential, 2011.

Tvalchrelidze A. Silagadze, A. Keshelashvili, G. Gegia D. (2011). Georgia's Social Economic Development Program. "Nekeri", Tbilisi.

www.ifsdeurope.com/getdoc/34/Georgia\%20social\%20economic\%20development\%20program.pdf

Official web-page of Ministry of Agriculture of Georgia, http://moa.gov.ge

Official web-page of National Statistics Office of Georgia, http://geostat.ge/

Official web-page of Agricultural Cooperatives Development Agency, http://www.acda.gov.ge

Official web-page of International Co-operative Alliance, https://ica.coop/

Official web page of $\mathrm{FAO}$, www.fao.org.

Official web page of World Bank, www.worldbank.org. 